\title{
The Catastrophic Impact of Right
}

\author{
Agata Mihaela Popescu \\ "Dimitrie Cantemir" Christian University of Bucharest, Faculty of Juridical and Administrative Sciences, Romania, \\ av.agata@yahoo.com
}

\begin{abstract}
Each human being on planet Earth has his/her own place under the sun, a house, a country, and also freedom which enables the person to change all these how everyone wants or simply obliged to do so. Some people emigrate leaving their own country when the political regime changes, and when economy and security orders are destroyed, like the things happened in 1989. Following that catastrophe launched in the name of democracy, millions of people have remained jobless, homeless and hopeless. Ohers have left their country because God Mars has caused crises on their mother's land, the way things take place in Syria, in Northern Africa, and of course in many other places on the Blue Planet nowadays. This type of migration, in the high technological century in which hypersonic speed is practised, has not contributed to improving migratory people's human condition, it led on the contrary to humanitarian, demographic, existential and catastrophes of civilization. The migrating human floods that have covered Western Europe - the praiseworthy tree - have generated such effects, that by respecting proportions, they could be comparable to those produced by the Second World War. Suddenly, the great European capitals, the perils of the western civilization settled there thousand years ago (as a result of the battles they had always won), have found themselves overrun by Moslems, Africans, Asians and other peoples who shuddered the West, like the crusaders had terrified the East centuries ago. The huge economic power and the Western grand resources of civilization have not succeeded either to blur such phenomenon or to assimilate immigrants. Thus, one of the most human Man's right - the right to migration - has generated a nightmare in the most civilized and elegant places on the Earth.
\end{abstract}

KEYWORDS: counter-civilization, despair, migration, phenomenon, port-terrorism, terrorism

\section{Introduction}

So far, the major existential questions, so persistently asked, even nowadays, have not been taken too seriously; at the most, they have generated an exercise of probabilistic calculus, conditioned or not by meditation in "maybe" and by imagination in "possibly". There was and there still is enough room for everybody under the sun. This assertion, placed somewhere between categorical and apodictic, is increasingly being doubted. Despite the fact that Earth, as long as it has a cosmic and a geophysical life the first being a way of existing and the second a way of being - tends to settle and self-settle its endogenous accounts, among which the demographic ones. Since, according to some analyses, the demographic factor begins to be a threat, not only to itself, in the people's capacity as greedy consumers of resources, but also to the planet. For how long? The answer to this second logical question also falls in the area of conditioned possibilities and probabilities.

We shall see. When the overpopulation issue becomes critical, most probably Earth will find the most appropriate solution. Until then, people - these bipedal beings on earth, who contradict the law of the three stand-on points - will keep looking for a better place under the sun, governed, first of all, by their bio-psycho-social condition and by their own way of living, while taking exoplanets into consideration as well.

It is difficult to say why people are the way they are. As it is equally difficult to search for the sense and non-sense of man's existence on earth. There is a very complicated and interminable battle among human communities for an as good as possible place on earth and under the sun, that is for resources, for markets and for security, but this battle is more than a competition. This is more than about something arising from something else; this is about a complicated and unlimited war, with variable and fluid, conscious and unconscious belligerents, who carry on - in each era, with its own means - a confrontation begun probably with the first man who saw beyond what could be seen.

In his famous book The Clash of Civilizations ... Samuel P. Huntington (1997, 34; 290-303) shows that from the seven or eight civilisations existing on Earth (Western, Orthodox, Islamic, Sinic, Japanese, Hindu, African and Latin American - the last one could be included in the Western civilisation), the Western civilisation is the most aggressive, and the major war of this century, if there is 
one, will be an inter-civilizational war, primarily between the Muslim and the western civilisations. It is difficult to understand which could be the reason for such a war, but, anyhow, it exists, in all possible formulas, from the conceptual to the military ones. People fight for almost everything: for soil and subsoil resources, for earth and sky, for real and virtual space, for ideas, for concepts, and particularly for power and influence. The expanded war, the unlimited war, the cognitive war, the power war, even the Luciferian war, or whatever it is called, is common nowadays. We have been fighting for as long as we exist.

After the end of the Cold War, nobody felt relieved. The communist East began its battle for integration in the Western world, the eternal West continued the one for the assimilation of the Eastern world, and this clash resulted firstly in the disaster in the space of the southern Slavs, in the Middle East, in Northern Africa and in the rest of the world. The end of the Cold War did not mean the end of any type of war and the establishment of peace, prosperity, freedom and security, but the continuation, by all possible means - from economic and financial means to the cognitive, media and military ones - for geopolitical and geostrategic resettlements and reconfigurations, for oil and natural gases, for the repositioning and pre-positioning of positions, forces, means, ideas and concepts (Frunzeti, Mureșan, Văduva 2009, 191-194, 335-338, 384). While disasters, in the name of durable welfare and remaking, have unsettled the East and the West, the North and the South, the Middle East, the Near East, and Northern Africa, revived the terrorist scourge, the terrorist war and the anti-terrorist war, the "Arab spring" and the tragedy in Syria, the rearmament of the great powers, the beginning of the hypersonic era and more particularly, have regenerated the migration phenomenon.

\section{Is present migration the expression of a right or the effect of a war?}

It is difficult to understand whether the present migration is an expression of the unlimited war we have been speaking about for some time now, one of its forms, a massive, complicated and subtle offensive means, a complex and violent vector of a commandment (civilizational or not, identity-related or not) to destroy another civilisation, or just an effect of the real war fought in the world today. It is certain that millions of people have left their native land in order to avoid death, to find a job and a shelter, or to access another existential horizon, another dimension of their own way of being. And this is an essential right (Buzatu 2018, 195).

Is present migration similar to that of ancient times and the Middle Ages or is it different? Do people run away from the native evil land, hoping to live by the promised "tree" or anywhere else a life better than at home? In other words, is present migration an existential option, associated to a human right - right to life, to work, to dignity, security and prosperity - or a vector used by a commandment in an inter-civilizational war? Is present migration a form of the inter-civilizational war mentioned by Samuel P. Huntington, or only a natural movement of populations caused by the new developments, the new pressure and present opportunities (Cristiean 2016, 275)?

Certainly, in the era of state-of-the-art technologies, of fast transport, of global communication in real time, of cogno-civilisation generation, of space virtualisation and time compression, the individual is expected to live simultaneously in several places on the planet Earth - this being today not only possible but also necessary - but the dramatic migration we speak about in this paper is not entirely just an expression of this modernity, of world globalisation, of the civilizational threshold reached, of the need for synthesis, of the new geopolitical constructivism, but also an expression of its tragic nature, of the violent and dramatic uprooting of ethnic, religious and civilizational groups, ultimately of people, of a new type of human mobility without frontiers, generated by corporatism, by network and a new modus vivendi on Earth.

Migration is a real, visible phenomenon, which generates numerous and complex effects, and not only a possible, predictable and manageable one. Western Europe is actually invaded by desperate Muslims, Africans, Asians who want to escape from what there is at home, and what there is at home seems to be, to a large extent, an effect of the great and eternal fights of powers for power. 


\section{Migration typologies and levels}

There are at least four typologies of present migration. At a first glance, they show that it is not a chaotic and tempestuous incursion, a panicky movement of population to anywhere, or a mere getaway into the world, especially to that Western European and American heaven built in millennia by using at discretion the resources of the entire planet, but a complex phenomenon with both objective and subjective causes, specific to the beginning of this century.

In our opinion, we are dealing with a migration of brains, with an endogenous migration of European populations, with an Arab-Muslim and Northern African migration to Western Europe, of Mexicans and other populations to the United States etc., and with an Asian, mostly Chinese, but also Muslim migration to the Russian Far East and to other places seen as either safe or important for what they are or for what they are to become.

It is common knowledge that most of the people of special intellect and particular intellectual abilities have always looked to the important European and American cities where they have found all the conditions that allowed them to be most efficient. It happened in the past, it is happening today. The Romanian Olympics dream to get to Paris, London, Berlin, New York, and nobody can stop them. Likewise, the major Western capital cities, the great Western universities have always attracted brains and helped them turn into what they are today. Tesla, Coandă, Oppenheimer, Mircea Eliade, Brâncuși and so many other geniuses would not have become what they became if it had not been for the great Western schools. And the Western world would not have become what it is today had this brain drain not taken place.

There has been a European endogenous migration ever since Europe exists. Although, in the meantime, states have settled one way or another, they have always had and will have to share not only concepts, theories, values and interests, but also brains, experts, projects and programmes, workforce and resources. This has always happened and this is still happening today.

Despite this endogenous migration generated by the broken East-West bipolarity, walls and curtains built following a complicated and continued series of fratricide wars, the Europeans must draw their extremes closer and rebalance their equilibria and projects on self-centred efforts to reclaim a lost ideal - that of unity and brotherhood of a continent that has generated incommensurable values on which heroes and martyrs had risen and died - as well as a project meant to lead to the cessation for good of a catastrophic endogenous conflict materialised in two World Wars, and to a possible and absolutely necessary real, constant and beneficial to everyone European unity.

The Arab-Muslim extremists, who today are between the vectors of the war the Islamic civilisation wages against the Western civilisation and the rest of the world (or only against the Western civilisation considered aggressive, immoral and extremely dangerous) and the tragedy of its uprooting by the Western world through assimilation, division or destruction, seem to be the new spearhead and, at the same time, the new target in a new merry-go-round of world conflicts. As it is well known, part of the Muslim countries - Saudi Arabia, Iran and other Middle East states, as well as Turkey, a NATO member state - are arming themselves. The Islamic State wants to create a new caliphate. The previous one was the Ottoman Empire.

The end of the $20^{\text {th }}$ century and the beginning of the $21^{\text {st }}$ century were shaken by a bloody IraqIran war (September 1980-August 1988, that left huge damage and casualties behind), by the war of the coalition led by the United States, in 1991 and 2003, against the dictatorial regime of Saddam Hussein in Iraq, by the wars in Afghanistan, by the war in Libya, by other wars generated by the "Arab Spring" etc. and, more recently, by the war in Syria. The wars and all the other conflicts that erode the ArabMuslim world can be seen, on the one hand, as the effects of policies and strategies of the Western civilisation meant to maintain the Arab-Muslim world divided, in tension and inner conflicts, and, on the other hand, as a modality of freeing the world from dictatorships and authoritarian leaderships and of building a democratic and prosperous Middle East, as Georg Bush said, which should no longer pose a threat to the Western World and allow for an unlimited access to the cheap power resources it boasts. But what happens all over the Middle and Near East at present can also be seen as an asymmetric reaction of a non-homogenous civilizational identity in an ancient but permanently reactivated strategic crevice. 
Hence more and more questions related not only to civilisation geopolitics but also to a modus vivendi of power, living and survival on the planet Earth. Is the Muslim civilisation arming itself? Is it preparing for a life-and-death war with the Western civilisation, with the Orthodox civilisation and with the rest of the world? Do the Muslims want to generate an over-the-centuries replica of the Crusades? Is this Muslim migration to the heart of Western Europe planned by its leaders, who want to turn the world (or a large part of it) into a great caliphate, as the Islamic State claims? Or is this migration planned by the Western civilisation itself in order to destroy its unity, to dilute it and to annihilate its power? Can six and a half billion of non-Muslims on the planet Earth assimilate or destroy one billion Muslims ... Does any of the power circles in the world somewhere have such a simplistic and primitive vision?!

After all, there always have been migrations. It seems that the world keeps moving to the West, to close the circle of civilisations on Earth. When the migratory warrior populations from the Euro-Asian geophysical platform reached the Atlantic and their elites settled down in Western Europe, it was not the end but a respite to cross the ocean... The Pacific followed... The Asian East brought populations, ideas and questions to the European West. The European West generated culture, knowledge and a civilisation which it exported and imposed to the West beyond the West. Modern America generated democracy and global power. And Admiral Mahan told the Americans that sea power was very important to controlling the seas, and he who dominates the sea dominates the world. America is at present the only power that dominates the sea and has deployed forces and means in over 700 military bases all over the world and in all areas of vital interest ...

The deployment of American troops and equipment all over the world do not cover the migration issue but only the control and strategic supervision of the vital centres in all the areas man has access to. The fact that the United States allot over 636 billion dollars to defence expenses - more than the first ten armies of the world taken together - points, on the one hand, to the colossal strength of the United States, to the huge military expenses this superpower covers as major NATO member state, even if they have decreased as to the previous years, when the allotment percentage was $4.03 \%$ of the giant American GDP, and, on the other hand, to the extremely fluid and difficult issue of security and defence when the international situation becomes ever more tense and uncertain, and the development of weapons and other combat means has reached unprecedented levels, entering the hypersonic era.

The Arab-Muslim migration to Europe is not only the reality of securing insecurity by accessing the right to immigration and to protection from the other states which can provide them, but also the danger posed or that can be posed by the effects of such a massive and tempestuous migration. The fact that populations flee conflict zones, seeking shelter and protection in rich and safe countries is a right and, equally, a very good thing. But the disruption of the balance and demographic structure in some of the richest and most powerful states of the world, the enclavisation or self-enclavisation, often aggressive, of immigrants, with the banning of the access of the autochthonous population and even of the authorities of the respective state, with demonstrations against the order of law and the authority of the host country and the use of the immigrant flows to infiltrate cells of the Islamic State and of other terrorist organisations created and still create extremely grave situations and a fluid and perverse danger, highly difficult to assess and thwart.

On the one hand, the moving drama of the populations fleeing their countries, which are in a state of war, in order to stay alive, get help or find a job, and, on the other hand, the use by the Islamic State and by other terrorist organisations, by Jihadists in general, of these flows and communities in dramatic situations, as terrorist bearing vectors to harm Western civilisation and everyone that is non-Islamic, represent, in large areas, serious and complicated situations which generate a political, civic, economic and more particularly strategic configuration unheard of so far and a paradoxical geopolitical effect which, in time, can actually end in the destruction of a civilisation and matchless heritage.

The supports of causative determinations of this unique phenomenon in the modern history of mankind are numerous. First of all, the strategic crevice, opened as early as the peace of Westphalia between the Muslim civilisation, on the one hand, and the Christian civilisation, on the other hand, maintained by the following wars and somehow ameliorated, during the nations period, reopened today, especially after the September 2001 terrorist attacks in the United States on the World Trade Center, the 
Pentagon and, unless timely measures had been taken, even on the White House - all three being symbols of the Western civilisation, of the financial world and of the global power of the United States.

Even if those tragic events are considered to be the outcome of madmen, their actions continued. Certainly, they are not directly linked to the migration phenomenon, but they are the peak of the endogenous conflictual situation in today's world, when a religion generates a death war against another concept and another religion. This extremely serious conflict is related not only to resource control, to wealth and poverty, justice and injustice, but to two different, irreducible and irreconcilable ways of living. This seems to be a rather serious motive to start a war against another war, subsequently justified by tens of ever more complex and sophisticated reasons.

Certainly, beyond the ethics of such a conflict - ethics that pertains to a modus vivendi - there is a huge range of interests of the power centres, of the groups that control important segments of the world, of states, identities and non-state entities, of networks and all kinds of circles that have generated events, conflicts and particularly devastating wars of a larger or smaller scope, and of an intensity carefully watched over and rather well controlled. Even the migration phenomenon could possibly be generated and maintained deliberately - at least in certain segments. But, for populations, for states and even for civilizational identities, these developments in the name of a sacred right, the right to life and to security, already have an economic, geopolitical, geostrategic, military and, chiefly, a devastating human impact. The Western order is gradually destroyed, communities are forced to bear the unbearable, and the circles of interest, the terrorist networks and those of organised crime take full advantage of the situation. Unfortunately, human condition suffers most.

Each individual is a unique and non-repeatable being on the planet Earth ad in the Universe. But this being can exist only in communities and under specific social conditions. Even if the construction of what we may call cogno-civilisation - a civilisation whose essential values are cognitive - has already begun, the individual cannot leave his area of ideals and sensibility, cannot depart from what he is among the other people and together with them, as well as alone, anchored in his own existence.

The present migration, triggered by both the end of the Cold War and the beginning of the Unlimited War, and by the European endogenous state of conflict, by the induced and vector migration, bearer of a devastating impact (for example, the destruction of Western and national heritage and culture), has and can have highly complex consequences. Nothing is going to be as it used to be.

In Romania, for example, the new wave of reforms and changes, that began shortly after 1990, which nobody has fully understood but only accepted as democratic mottos and slogans, has destroyed almost everything that had been established in a century, wasted the national wealth, devastated the natural environment, the forests and farmland, irrigation systems, the thousands and economic companies that operated, produced and sold their products all over the world, almost killed trust and even hope.

According to EUROSTAT statistics, Romania ranks fourth in Europe in point of migration with 3.4 million of immigrants. Ranking first is Great Britain with 4.9 million, second is Poland with 4.4 million, and third is Germany with 4 million. If we correlate these figures with the number of inhabitants, the situation changed completely: Romania comes first, with $15.9 \%$ immigrants (3.4 million of 21,529,867 inhabitants (CIA 2018), second comes Poland, with 12.03\%, (4.4 million of 36,426,269 inhabitants), and third comes Germany, with 4.96\%, (4 million of 80,594,017 inhabitants).

As a matter of fact, the percentage of the Romanians that went abroad to find a job is by far higher. In 25 years, Romania lost, due to migration, 17\% of its inhabitants (Stirile Pro.Tv 2016). In very many settlements, rural in particular, the number of inhabitants halved. And those who stayed behind, in villages anyway, are old people who can no longer toil the land. Actually speaking, nobody (not even the National Institute of Statistics - NIS) knows exactly the real number of Romanians who left in search of a job, since the fluctuation is very high. Some go to various Western countries only during the harvesting periods (by minibuses, buses, personal transport means), for seasonal jobs (for a few months or a few days), some work occasionally, whenever they find work, gypsies go begging, while those populating some of the organised crime networks are hardly detectable, and it is almost impossible to know their number. 
Romanians' moral expectations, a safe tomorrow, confidence in the country's leaders - regardless of political orientation and programmes - are eroded, the society is disrupted, there is not country programme expected and accepted by everybody, while national ideals, once extremely strong and optimistic, have almost died out. The country's arable soil - once the soul, pride and strongest love of each Romanian - has been sold, for no reason and with no horizon, in a proportion of $40 \%$, the forests have been savagely cut, the climate, once generated and controlled by the ecological balance of the land, has degraded, the irrigation systems have been destroyed, and their restoration, already begun over the past few years, will take at least one decade.

In other words, Romanian migration - the first in the millenary history of this sedentary people, slave and product of this land - has destroyed not only the order but also the entity of this nation characterised by steadiness, diligence and respect for the land, in the spirit of the philosophy of the land where it came into being and developed along the centuries.

The massive migration to the West - we speak about several millions of Romanians - has actually depopulated the country, depleted its highly and even medium skilled workforce. There no longer are enough vocational schools, the capital invested in the Romanian economy stands at less than $8 \%$, the lack of culture and illiteracy increase at a fast pace, while human condition erodes with every passing day.

People no longer trust their future, their expectations are limited, with no optimistic horizons. Many of those who went abroad have settled there, and no longer want to come back home, although some of them have built beautiful houses in their native places with the money earned in the Western countries. Many villages boast handsome houses which, unfortunately, are not inhabited.

After 1990, the entire financial system of the country and almost all the profitable and modern enterprises of Romania, boasting state-of-the-art technology for those times, bought with a lot of money from Western countries, were destroyed in several years, under the pretext of privatisation, hence of profitability, the Romanian state got indebted, senselessly and with no expectation horizon, to the IFM, to banks, without justifying such a course of action to the nation.

Almost all our attempts and all our programmes are influenced, and even conditioned one way or another, by the Romanian migration to Western Europe, by our experience in this corner of the world, so intense and dramatic to us. The Romanian migration has emptied the country of brains, ideals, and particularly of skilled people. The country has already aged, the population decreased numerically and qualitatively (and continues to decrease), the natural birth rate being negative (-3.0 in 2013, -3.1 in 2014, -3.2 in 2015 and -3.5 in 2016), while its participation in the settlement of the country's problems is apathetical, insignificant and sceptical. Most of the political leaders lack political and strategic culture, the norm of law does not enjoy the citizens' trust and respect, even if they still pins their hopes on equity and justice, this nation, heavily tried by history, but warm, hospitable, temperate, intelligent and diligent, is divided, sceptical as regards its future, and disappointed.

This is, by and large, the reality as concerns the effects of the Romanian migration seen from the inside. This migration is endogenous. The Romanians who left for Spain, Italy, France, Germany, Switzerland, Great Britain or any other European country do not consider themselves completely uprooted, gone away for ever, but only forced to stay away temporarily until better times come for them and for the country, so that they could provide for their family and upkeep the house. In a way, in Romania there is a feeling of thankfulness to the European states which have welcomed the Romanians and helped them in difficult times. Why is this country, blessed by God with everything it needs to be happy, passing through difficult times is another disturbing question which saddens the intelligent Romanians who understand the tough times they are going through.

For Romania, this type of migration is the first in its millenary history. It cannot be compared with the Arab-Muslim migration. The highly trained Romanians - physicians, teachers, engineers, highly skilled workers, graduates from Romanian or foreign higher learning institutions etc. - are European citizens, perfectly integrated under the conditions required by the countries where they live, and most probably many of them will remain there forever. Even if for them, just as for any other European citizen, this situation is acceptable, for Romania this is an irretrievable loss, especially when the labour 
market in Romania cannot offer much and its requirements are not fully consonant with the continuous learning system.

The attempts made over the past years to harmonise the education and continuous learning system with the requirements of the labour market, despite the projects implemented, are far from the real demands of the country, catastrophically shaken by the tempestuous destruction of the national economy, by the imposed migration and the incapacity of the political leadership and of the economic managers to solve the thorny problems of the country's transit to the market economy and of making the best of an efficient system for the capitalisation of natural resources and human potential.

\section{Conclusion}

The intra-European endogenous migration, generated and stimulated by the enlargement of the European Union, by the new integrationist philosophy of this new type of identity, by the norm on community law, as well as by a joint European economic, social and educational project, has contributed to the stimulation and speeding up of a better and more consistent mobilisation of human resources, of the highly trained ones in particular, for the benefit of both large corporations and European citizens, of those from Eastern European state in particular. This project, initially non-unitary and unsubstantiated by a thorough impact study, had and still has extremely different effects, ranging from disaster to sublime. It provided opportunities to the cheap but highly skilled labour force to find well paid jobs fast in Western countries, in strong companies, but not to the countries where from this labour force originated and to which it owed loyalty, gratitude and the effort needed to economically, socially and educationally adapt it to the new status. Thus, the migration of physicians, engineers, teachers, highly skilled workers and technicians with no jobs in their native countries, resulted in a great loss for the respective states.

For Romania - which did nothing to preserve and update its economy, learning system, health and security systems but was pleased with easy solutions of fraudulent privatisations - the migration of highly skilled/trained labour force was a disaster. This non-degradable, highly valuable human potential could never be retrieved, compensated or recreated.

The Arab-Muslim, Asian and Northern African migration to Europe is so complex, dynamic and tragic that it is hard to assert and understand whether Europe has the strength to cope with this huge challenge or will have to face a new civilizational reconfiguration.

\section{References}

Buzatu, Nicoleta-Elena. 2018. "The Migrant Smuggling Crime in Romania". In The 8th International Conference on Social Sciences and Humanities, Washington, DC: The Scientific Press.

Huntington, Samuel. 1997. Ciocnirea civilizaţiilor (The Clash of Civilizations). ANTET Publishers.

Frunzeti, Teodor, Mircea Mureșan, Gheorghe Văduva. 2009. Război şi haos (War and Chaos). Bucharest: CTEA Publishers.

Cristiean, Victoria. 2016. "Theoretical Aspects of Human Trafficking in the Light of the New Criminal Code provisions". In the Strategic Universe Magazine no 1.

Stirile Pro.Tv. 2016. Romania has entered the TOP 5 of countries with most emigrants. https://www.stirileprotv.ro/stiri/social/3-4-milioane-de-romani-locuiesc-in-diaspora-datele-care-arata-ca-inca-sunt-inpermanent-contact-cu-tara.html.

Central Intelligence Agency (CIA). 2018. The World Factbook. Washington, DC: Central Intelligence Agency. Continually updated. https://www.cia.gov/library/publications/the-world-factbook/fields/2119.html\#pl. 